\title{
IMPACT OF USING ADULTERATED AUTOMOTIVE DIESEL ON THE EXHAUST EMISSIONS OF A STATIONARY DIESEL ENGINE
}

\section{MATTHEOU* \\ F. ZANNIKOS \\ P. SCHINAS \\ G. KARAVALAKIS \\ D. KARONIS \\ S. STOURNAS}

Received: $15 / 05 / 06$

Accepted: 12/07/06

\author{
Laboratory of Fuel Technology and Lubricants \\ Chemical Engineering Dept \\ National Technical University of Athens \\ 9, Iroon Polytechniou str, 15773 Zografou Athens, Greece
}

\begin{abstract}
The EU Directives and legislation by worldwide environmental authorities impose constantly lower levels for the airborne pollutant emissions of internal combustion engines towards the goal of zero emission vehicles. During the last decade, engine manufacturers, refiners and fuel companies invest highly in order to comply with the increasingly severe emission requirements.
\end{abstract}

The diesel engine is widely used for transportation, manufacture, power generation, construction and farming operations. There are different kinds of diesel engine depending on their application: small, high speed, indirect-injection engines or low speed, direct -injection behemoths with cylinders more than one meter in diameter. Their main advantages are the efficiency, economy and reliability. The physicochemical properties of the diesel fuels and the engine design affect the operability, the efficiency and the performance of the diesel engine and they correlate to the exhaust emissions.

In Greece, the diesel fuel market steadily increases during the last years. The fuels produced by the refineries usually comply with the existing specifications. However, alterations in the fuel properties may occur through the supply chain to the service stations due to failures of the distribution system (i.e. contamination with water, tank sludge and residues) or adulteration with lower value and taxation fuels (heating oil, marine diesel or industrial solvents).

The transportation sector is a major source of air pollution. It contributes to harmful exhaust emissions, such as greenhouse gas emissions, carbon monoxide, sulfur oxides $\left(\mathrm{SO}_{\mathrm{x}}\right)$, nitrogen oxides $\left(\mathrm{NO}_{\mathrm{x}}\right)$, unburned hydrocarbons $(\mathrm{HC})$ and particulate matter $(\mathrm{PM})$ emissions.

In this paper, PM and exhaust emissions from a stationary single cylinder diesel engine were examined. For comparison purposes, tests were carried out with a typical automotive diesel fuel of the Greek market and with adulterated fuels with heating oil or white spirit. The noncomplying diesel fuels gave increased emissions in all cases with only exception the PM emissions due to adulteration with white spirit. More specifically, the experimental results for the adulterated fuels with heating diesel showed an increase of the nitrogen oxide emissions up to $73.9 \%$, of the unburned hydrocarbons up to $29.6 \%$ and of PM up to $121 \%$ compared to the baseline diesel fuel emissions.

KEYWORDS: Air quality, exhaust emissions, automotive diesel fuel, industrial solvents, adulterated fuels, white spirit, particulate matters 


\section{INTRODUCTION}

Air pollution caused by diesel emissions, especially $\mathrm{NO}_{x}, \mathrm{PM}, \mathrm{CO}$ and unburned hydrocarbons $(\mathrm{HC})$, has been a noteworthy matter. Extended research on the effects of fuel properties on the emissions and engine performance has been performed worldwide [1-3].

Diesel engines are designed to fulfill a set of emissions certification limits, where the fuel is a major design parameter. The fuels produced by the refineries usually comply with the legislation, but alterations in the fuel properties may occur during their transportation and up to the point where the fuel is dispensed into the consumer car tanks for a number of reasons.

It is common practice to adulterate automotive diesel with industrial solvents like white spirit to pass technical vehicle inspections reducing exhaust emissions. Furthermore, the large price difference between heating Diesel and automotive Diesel, due to the different tax policy, is the main motive for adulteration [4]. The heating Diesel of the Greek fuel market is colored red and contains solvent yellow 124 as a chemical marker at a proportion of $6 \mathrm{mg} \mathrm{l}^{-1}$. It also has sulfur contents up to $2000 \mathrm{ppm}(0.02 \mathrm{wt} \%)$.

In this paper, exhaust emission measurements from a single cylinder, stationary Diesel engine were examined. The engine was fueled with automotive diesel fuel (baseline diesel) and heating diesel from the Greek fuel market. Proportions of $25 \%, 50 \%$, and $75 \%$ of heating diesel in the baseline fuel were also used. Furthermore, the baseline diesel fuel was blended with white spirit at proportions of $10 \%, 15 \%$, and $20 \%$. The quality parameters of the automotive diesel fuel, heating diesel, and white spirit were also examined according to the European Specifications. The results showed that this kind of adulteration led to increased emissions with exception the PM emissions on adulterated automotive diesel with white spirit.

\section{EXPERIMENTAL PROCEDURE}

A stationary, Diesel powered Petter engine, model AV1-LAB, was employed. The engine characteristics are cited in Table 1. The engine was fuelled with neat automotive Diesel and adulterated mixtures containing $25 \%, 50 \%, 75 \%$ and $100 \%$ heating Diesel and $10 \%, 15 \%$, $20 \%$ white spirit. The emission tests included $\mathrm{HC}, \mathrm{NO}, \mathrm{NO}_{\mathrm{x}}$ and $\mathrm{PM}$ emission measurements under various loads up to $5 \mathrm{hp}$, the load being measured by shaft output. Two exhaust emission analyzers were used. The specifications of the emissions analyzers are cited in Table 2.

Table 1. Stationary Petter AV1-LAB engine

\begin{tabular}{ll}
\hline Engine type & single cylinder, indirect injection \\
Speed & $1500 \mathrm{rpm}$ \\
Total displacement & $553 \mathrm{~cm}^{3}$ \\
Compression ratio & $19 / 1$ \\
Maximum output: & $3.7 \mathrm{~kW}(5 \mathrm{hp})$ \\
\hline
\end{tabular}

The analyzers, were supported by Exhaust Gases Transportation Heated Lines (Signal Instruments Co. model 530/540) and a Prefilter (Signal Instruments Co. Prefilter Unit 333) that restrains the emitted particulates from entering the Horiba and Thermo Environmental analyzers.

The measurement procedure for the $\mathrm{PM}$, equipment recommended by the Western Precipitation Division, Joy Manufacturing Company was used. According to this method, the exhaust gases pass through a fiber glass filter, while the flue gas volume is recorded by using a gas meter. PM weight results were obtained by subtracting the weight of the clean fiber glass filter from its weight at the end of the experiment, after drying. The procedure followed is shown in Fig. 1. The filters used were glass micro fiber by Whatman, Grade 934-AH. 
Table 2. Specifications of the exhaust emission analyzers

\begin{tabular}{|c|c|c|c|c|c|}
\hline \multirow{3}{*}{$\begin{array}{l}\text { Emission } \\
\text { Method } \\
\text { Operation } \\
\text { range }\end{array}$} & \multicolumn{2}{|c|}{$\begin{array}{c}\text { Thermo Environmental Instruments } \\
\text { Inc (42C NO-NO2-NOx Analyzer } \\
\text { High Level) }\end{array}$} & \multicolumn{3}{|c|}{$\begin{array}{c}\text { Horiba MEXA 574-GE } \\
\text { (gauges } \mathrm{HC} \text {, and CO exhaust } \\
\text { emissions) }\end{array}$} \\
\hline & $\begin{array}{c}\text { NO, ppm } \\
\text { Chemil }\end{array}$ & $\begin{array}{l}\mathrm{NO}_{x}, \mathrm{ppm} \\
\text { cence }\end{array}$ & $\begin{array}{c}\text { HC, ppm } \\
\text { NDIR }\end{array}$ & $\begin{array}{c}\text { CO, vol\% } \\
\text { NDIR }\end{array}$ & $\begin{array}{c}\mathrm{CO}_{2}, \mathrm{vol} \% \\
\text { NDIR }\end{array}$ \\
\hline & $0-5000$ & $0-5000$ & $0-10,000$ & $0-10.00$ & $0-20.00$ \\
\hline $\begin{array}{l}\text { Accuracy } \\
\text { Precision }\end{array}$ & $\begin{array}{c}0.050 \\
\pm 1 \%\end{array}$ & $\begin{array}{c}0.050 \\
\pm 1 \%\end{array}$ & $\begin{array}{c}2 \\
\pm 20\end{array}$ & $\begin{array}{c}0.01 \\
\pm 0.05\end{array}$ & $\begin{array}{c}0.02 \\
\pm 0.10\end{array}$ \\
\hline
\end{tabular}

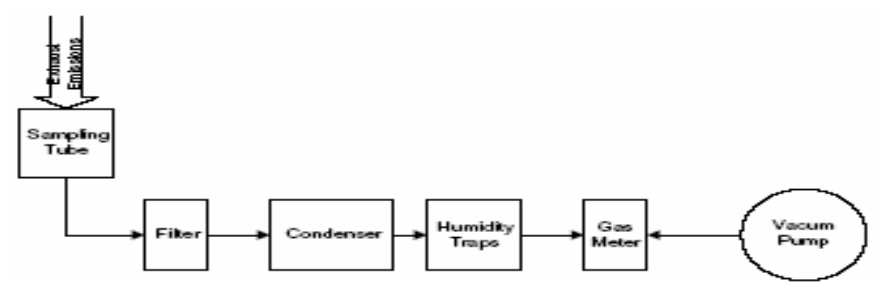

Figure 1. The sampling procedure for measuring PM.

Fuel was supplied by an outside glass tank of about 3 । capacity, which could easily be drained for fuel changes. For every fuel change, the fuel lines were cleaned, and the engine was left to run for at least $60 \mathrm{~min}$ to stabilize on the new conditions. No fuel filter was used.

\subsection{Test fuels}

The specifications of the automotive and heating Diesel fuels are presented in Table 3.

Table 3. Automotive and heating Diesel fuel properties

\begin{tabular}{|c|c|c|c|c|}
\hline Properties & Unit & $\begin{array}{c}\text { Automotive } \\
\text { Diesel }\end{array}$ & $\begin{array}{c}\text { Heating } \\
\text { Diesel }\end{array}$ & $\begin{array}{c}\text { Test } \\
\text { Method }\end{array}$ \\
\hline Density at $15^{\circ} \mathrm{C}$ & $\mathrm{kg} \mathrm{I}^{-1}$ & 0.8396 & 0.8426 & ASTM D 1298 \\
\hline Sulfur & wt\% & 0.0338 & 0.1336 & ASTM D 4294 \\
\hline Nitrogen & $w t \%$ & 0.0107 & 0.0155 & ASTM D 429 \\
\hline Distillation curve & & & & ASTM D 86 \\
\hline Ignition boiling point & ${ }^{\circ} \mathrm{C}$ & 183 & 184 & \\
\hline $10 \% \mathrm{v} / \mathrm{v}$ recovered at & ${ }^{\circ} \mathrm{C}$ & 233 & 221 & \\
\hline $50 \% \mathrm{v} / \mathrm{v}$ recovered at & ${ }^{\circ} \mathrm{C}$ & 285 & 281 & \\
\hline $90 \% \mathrm{v} / \mathrm{v}$ recovered at & ${ }^{\circ} \mathrm{C}$ & 340 & 350 & \\
\hline $95 \% \mathrm{v} / \mathrm{v}$ recovered at & ${ }^{\circ} \mathrm{C}$ & 358 & 374 & \\
\hline Final boiling point & & 368 & 378 & \\
\hline Copper strip corrosion & & 1 & 3 & ASTM D 130 \\
\hline Flash point & ${ }^{\circ} \mathrm{C}$ & 68 & 55 & ASTM D 93 \\
\hline Kin. viscosity at $40^{\circ} \mathrm{C}$ & $\mathrm{cSt}$ & 3.0 & 6.0 & ASTM D 445 \\
\hline Water & $\mathrm{mg} \mathrm{kg}^{-1}$ & 80 & & ASTM D 1744 \\
\hline Water and sediment & $\% \mathrm{v} / \mathrm{v}$ & & 0.1 & ASTM D 1796 \\
\hline Cetane index & & 53 & 46 & ASTM D 4737 \\
\hline Ash & wt\% & 0.005 & 0.02 & ASTM D 482 \\
\hline $\begin{array}{l}\text { Conradson carbon } \\
\text { residue }\end{array}$ & $w t \%$ & 0.02 & 0.30 & ISO 10370 \\
\hline $\begin{array}{l}\text { Cold filter plugging } \\
\text { point }\end{array}$ & ${ }^{\circ} \mathrm{C}$ & -11 & -5 & IP 309 \\
\hline Suspended matter & $\mathrm{mg} \mathrm{kg}^{-1}$ & $<24$ & & DIN 51419 \\
\hline Oxidation stability & $\mathrm{g} \mathrm{m}^{-3}$ & $<25$ & & ASTM D 2274 \\
\hline Net heating value & $\mathrm{kcal} \mathrm{kg}^{-1}$ & 10,280 & 10,259 & ASTM D 2015 \\
\hline
\end{tabular}

The white spirit industrial solvent specifications are presented in Table 4. 
Table 4. White spirit industrial solvent properties

\begin{tabular}{lcc}
\hline \multicolumn{1}{c}{ Properties } & Unit & White spirit \\
\hline Density at $20{ }^{\circ} \mathrm{C}$ & $\mathrm{kg} \mathrm{I}^{-1}$ & 0.7840 \\
Distillation curve & & \\
Ignition boiling point & ${ }^{\circ} \mathrm{C}$ & 161 \\
$60 \% \mathrm{v} / \mathrm{v}$ recovered at & ${ }^{\circ} \mathrm{C}$ & 181 \\
Final boiling point & ${ }^{\circ} \mathrm{C}$ & 204 \\
& Saybolt & +30 \\
Color & $\%$ vol & $10-20$ \\
Total aromatic content & & \\
\hline
\end{tabular}

\section{RESULTS AND DISCUSSION}

The experiments included emission measurements under various loads. The engine was fuelled with adulterated automotive Diesel fuels containing domestic heating Diesel fuel and industrial solvent white spirit in various proportions. The emission levels of the base fuel are cited in Table 5.

Table 5. Base fuel measurements on the stationary Petter AV1-LAB engine

\begin{tabular}{|c|c|c|c|c|c|c|}
\hline \multirow{2}{*}{\multicolumn{2}{|c|}{ Automotive Diesel fuel }} & \multicolumn{5}{|c|}{ Load (hp) } \\
\hline & & \multirow{2}{*}{$\begin{array}{l}0.1 \\
302\end{array}$} & \multirow{2}{*}{$\begin{array}{l}1.25 \\
490\end{array}$} & \multirow{2}{*}{$\begin{array}{l}2.5 \\
644\end{array}$} & \multirow{2}{*}{$\begin{array}{l}3.75 \\
648\end{array}$} & \multirow{2}{*}{$\begin{array}{c}5 \\
848\end{array}$} \\
\hline $\begin{array}{c}\text { NO emissions } \\
\text { (ppm) }\end{array}$ & Mean value & & & & & \\
\hline & Std deviation & 0.8 & 3.7 & 8.4 & 64.5 & 53.5 \\
\hline \multirow{2}{*}{$\begin{array}{l}\text { NOx } \\
\text { emissions } \\
\text { (ppm) }\end{array}$} & Mean value & 352 & 541 & 697 & 704 & 876 \\
\hline & Std deviation & 3.2 & 2.7 & 8.7 & 68.5 & 53.6 \\
\hline \multirow{2}{*}{$\begin{array}{c}\text { HC emissions } \\
(\text { ppm) }\end{array}$} & Mean value & 31 & 25 & 27 & 33 & 37 \\
\hline & Std deviation & 8 & 10 & 11 & 14 & 16 \\
\hline \multirow{2}{*}{$\begin{array}{l}\text { PM emissions } \\
\qquad\left(\mathrm{mg} \mathrm{m}^{-3}\right)\end{array}$} & Mean value & 11 & 18 & 39 & 52 & 79 \\
\hline & Std deviation & 0.8 & 0.7 & 1.2 & 1.7 & 2.3 \\
\hline
\end{tabular}

The proportions of heating diesel up to $75 \%$ in automotive diesel fuel presents a slight increase in $\mathrm{NO}$ and $\mathrm{NO}_{x}$ emissions, especially at low loads (up to $1.25 \mathrm{hp}$ ). At the same time, the increase of $\mathrm{NO}$ and $\mathrm{NO}_{\mathrm{x}}$ emissions above $2.5 \mathrm{hp}$ was significantly higher. The maximum value of the percentage change in $\mathrm{NO}_{x}$ emissions (above $70 \%$ ) occurred at the $100 \%$ adulteration (neat heating diesel), (Figs. 2 and 4). In accordance to figures 3 and 5 , the percentage change in $\mathrm{NO}$ and $\mathrm{NO}_{x}$ emissions remained relatively constant at all three concentrations of white spirit in the baseline fuel (ca $40 \%$ up to $5 \mathrm{hp}$ ). The increase in NO and $\mathrm{NO}_{x}$ emissions is mainly due to the lower cetane index of the adulterated fuels. This results in higher $\mathrm{NO}$ and $\mathrm{NO}_{\mathrm{x}}$ formation rates, since the combustion pressure increases in respect to the neat automotive Diesel, leaving less time for cooling through heat transfer and dilution and leading to higher localized gas temperatures [5]. It must be noticed that the Petter AV1$L A B$ is an indirect injection engine and therefore the maximum $\mathrm{NO}_{x}$ concentrations are expected to be at partial loads.

Other reasons include higher density, higher viscosity and back-end volatility, since the heating Diesel fuel contains heavier fractions that distill at higher temperatures than the automotive Diesel [6-9].

The percentage changes on PM emissions are outlined in figures 6 and 7 . The adulteration with heating diesel showed an increase in the PM emissions (greater than $100 \%$ in neat heating diesel). The reason for this difference is the sulfur content of the automotive Diesel $(0.0338 \mathrm{wt} \%)$ and the heating Diesel $(0.1336 \mathrm{wt} \%)$. The PM emissions decreased when the adulteration with white spirit occurred at all loads. The literature verifies that PM emissions 
generally increase or decrease in relation to the sulfur concentration. The sulfur content and the density of the white spirit as measured were relatively lower than the automotive diesel. Sulfur in the fuel results in sulfates that are absorbed on soot particles and increase the PM emitted from Diesel engines. In addition, the use of fuels with higher density results in higher emissions of PM and smoke [10-13].

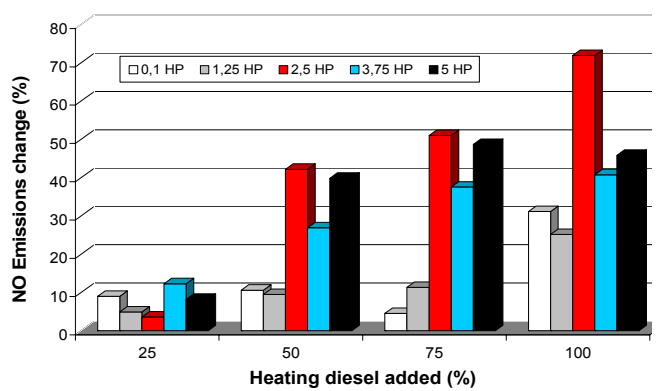

Figure 2. NO emissions change due to adulteration with heating Diesel

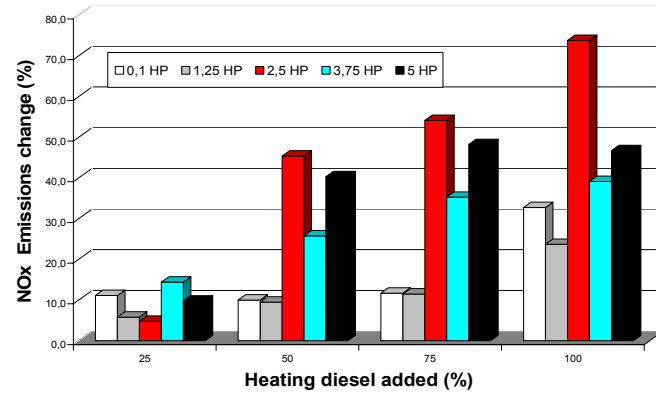

Figure 4. $\mathrm{NO}_{\mathrm{x}}$ emissions change due to the adulteration with heating Diesel

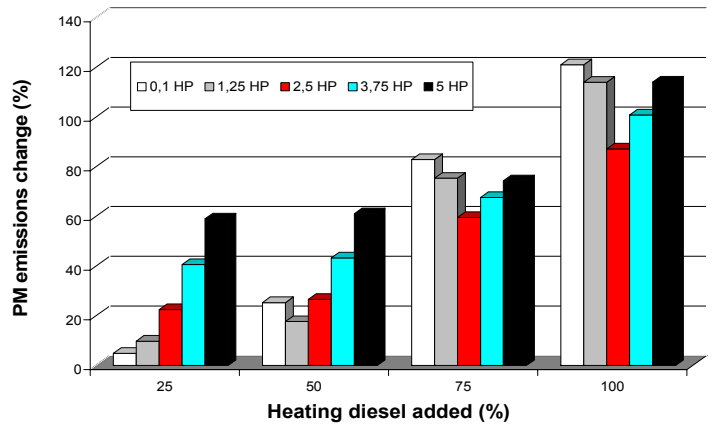

Figure 6. PM emissions change due to adulteration with heating Diesel fuel.

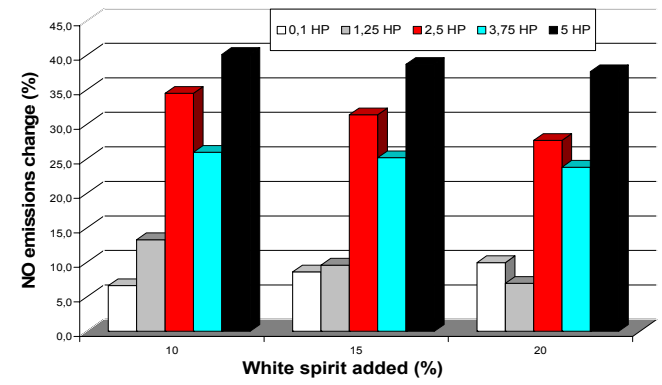

Figure 3. NO emissions change due to adulteration with white spirit

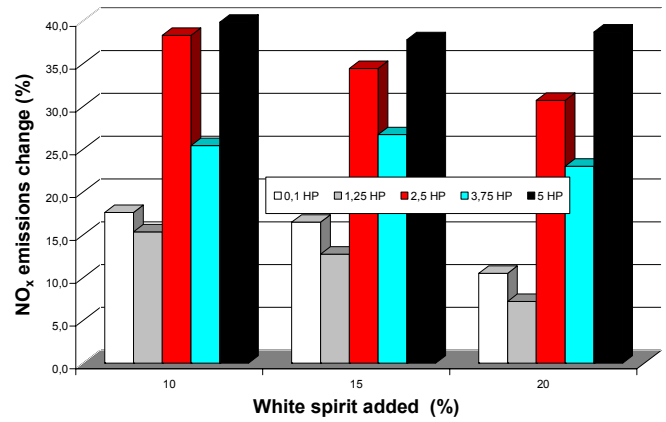

Figure 5. $\mathrm{NO}_{\mathrm{x}}$ emissions change due to the adulteration with white spirit.

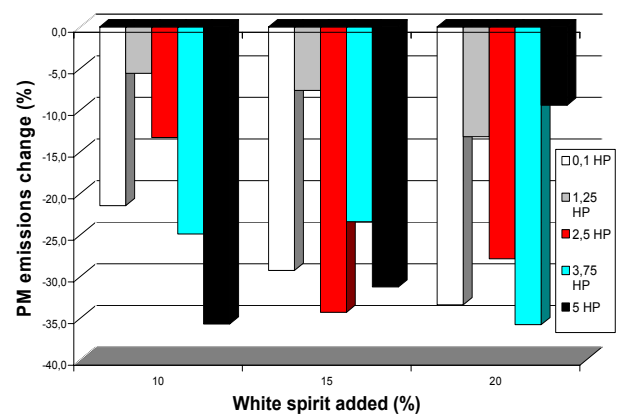

Figure 7. PM emissions change due to adulteration with white spirit

Figures 8 and 9 illustrate the percentage change of the hydrocarbon emissions due to adulteration of the automotive Diesel with heating Diesel or white spirit. An increase of HC emissions was observed, reaching their peak value at $75 \%$ adulteration level and exhibiting minimum values at the $100 \%$ adulteration level with heating diesel. There was also an increase in the $\mathrm{HC}$ emissions in the case of adulteration with white spirit. The peak value achieved at $15 \%$ adulteration level while the minimum values at the $20 \%$. Generally, Diesel engines emit small values of HC. A number of studies have concluded that increasing the cetane index has a beneficial effect on hydrocarbon emissions [9-14]. 


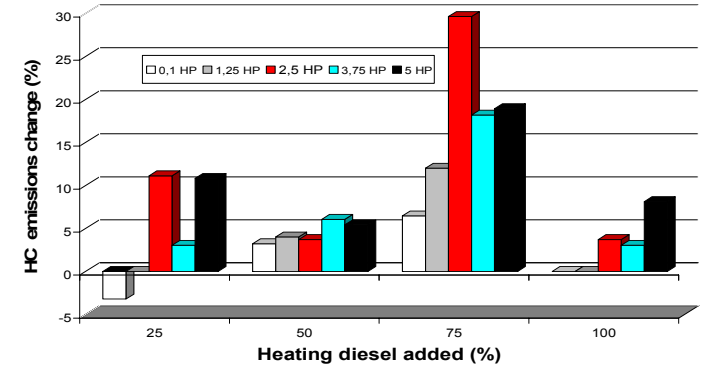

Figure 8. $\mathrm{HC}$ emissions change due to adulteration with heating Diesel fuel.

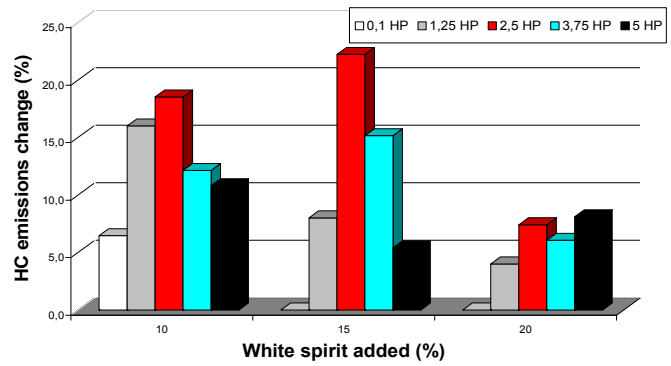

Figure 9. HC emissions change due to adulteration with white spirit.

\section{CONCLUSIONS}

The adulterated fuels increased nitrogen oxide, total nitrogen oxide emissions, particulate matter and unburned hydrocarbon emissions with the exception of the PM emissions percentage change on adulterated automotive diesel with white spirit. The results of this research are in accordance to the concerns of the European Union to promote the development of a uniform system for fuel quality monitoring.

\section{REFERENCES}

1. Kalligeros S., Zannikos F., Stournas S., Lois E., Anastopoulos G. (2004) Impact of using automotive Diesel fuel adulterated with heating Diesel on the performance of a stationary Diesel engine, Energy Conversion and Management (in press)

2. Tanaka S, Takizawa H, Shimizu T, Sanse K. (1998) Effect of fuel consumptions on PAH in PM from DI Diesel engine, SAE Paper 982648

3. Uchida M, Akasaka Y. (1999) A comparison of emissions from clean diesel fuels, SAE Paper 1999-01-1121

4. Laboratory of Fuel Technology and Lubricants, National Technical University of Athens (2000) Measures to decrease the air pollution from adulterated fuels, Final Report, Athens, Greece

5. Kidoguchi Y, Yang C, Miwa K. (2000) Effects of fuel properties on combustion and emissions characteristics of a direct injection Diesel engine, SAE Paper 2000-01-1851

6. Walsh MP. (1999) Global trends in diesel emissions control-a 1999 update, SAE Paper 1999-01-0107

7. Beatrice C, Bertoli C, Del Giacomo N, Migliaccio Mna. (2000) Experimental investigation on high-quality diesel fuels effects in a light duty CR Diesel, SAE Paper 2000-01-1911

8. Neill SW, Chippior LW, Guelder LO, Cooley J, Richardson KE, Mitchell K, Fairbridge C. (2000) Influence of fuel aromatics type on the particullate matter and $\mathrm{NO}_{\mathrm{x}}$ emissions of a heavy-duty Diesel engine, SAE Paper 2000-01- 1856

9. Stradling R, Gadd P, Singer M, Operti C (1997) The influence of fuel properties and injection timing on the exhaust emissions and fuel consumption of an Iveco heavy-duty diesel engine, SAE Paper 971635

10. Roy MM, Tsunemoto H, Ishitani H. (1999) Effects of injection timing and fuel properties on exhaust odor in DI Diesel, SAE Paper 1999-01-1531

11. Hublin M, Gadd PG, Hall DE, Schindler KP. (1996) European programmes on emissions, fuels and engine technologies (EPEFE) — light duty diesel study, SAE Paper 961073

12. Orban EJ, Tsai ChH. (2000) Statistical issues in the evaluation of the impact of sulfur in diesel fuel on the performance of Diesel particulate filter emission control devices, SAE Paper 200001-1958

13. Singal SK, Singh IP, Pandey DC, Runda MK, Semwal PB, Gandhi KK. (1999) Fuel quality requirements for reduction of Diesel emissions, SAE Paper 1999-01-3592

14. Martin B, Beckman D, Aakko P, Del Giacomo N, Giarazzi F. (1997) Influence of future fuel formulations on diesel engine emissions—a joint European Study, SAE Paper 972966 